\title{
The Students' Perspective of Using Instagram as a Writing Assignment Platform
}

\author{
Tenia Ramalia ${ }^{1}$ \\ Universitas Islam Syekh-Yusuf ${ }^{l}$ \\ tramalia@unis.ac.id ${ }^{l}$
}

\begin{abstract}
This study aimed to find out the students' perspective of using Instagram as a writing assignment platform. Using a qualitative research method, this study involved the students of the $2^{\text {nd }}$ semester in English Department Universitas Islam Syekh-Yusuf Tangerang. There were 61 students in writing class who were involved as the participants. It used the technique of survey with open-ended questionnaire as the instrument of data collection The results show that almost all students have positive perspective towards Instagram as a writing assignment platform. The participants found out that Instagram was fun, easy, and effective media to be used in doing writing assignment. Although, there were also some barriers in using it such as, bad internet network and privacy issue. It can be concluded that, Instagram can be one of useful teaching media, especially for writing, as long as it is used and supervised appropriately.
\end{abstract}

\begin{abstract}
ABSTRAK
Penelitian ini bertujuan untuk mengetahui perspektif siswa dalam menggunakan Instagram sebagai platform tugas menulis. Dengan menggunakan metode penelitian kualitatif, penelitian ini melibatkan mahasiswa semester 2 Jurusan Bahasa Inggris Universitas Islam SyekhYusuf Tangerang. Ada 61 siswa di kelas menulis yang terlibat sebagai peserta. Teknik pengumpulan data menggunakan teknik survei dengan angket terbuka sebagai instrumen pengumpulan data. Hasil penelitian menunjukkan bahwa hampir semua siswa memiliki perspektif positif terhadap Instagram sebagai platform tugas menulis. Peserta mengetahui bahwa Instagram merupakan media yang menyenangkan, mudah, dan efektif untuk digunakan dalam mengerjakan tugas menulis. Meskipun, ada juga beberapa hambatan dalam menggunakannya seperti, jaringan internet yang buruk dan masalah privasi. Dapat disimpulkan bahwa, Instagram dapat menjadi salah satu media pembelajaran yang bermanfaat, khususnya untuk menulis, asalkan digunakan dan diawasi dengan tepat.
\end{abstract}

\section{KEYWORDS}

Descriptive text;

instagram; teaching media; writing

\section{KATA KUNCI}

Teks Deskriptif; instagram; media pengajaran; menulis 


\section{INTRODUCTION}

The digital age has become a milestone of a new revolution in various fields, including education. Since the rapid development of technology, education is demanded to be able to use technology in implementing its learning activity so that all students are able to compete in the era of industrial revolution 4.0. Not only students, teachers must also prepare themselves for the development of technology. Besides mastering the field of competence, teachers should also master the sophistication of today's technology.

The complexity in teaching writing promotes challenges to the students/teacher. Writing is known as a complex skill, for it has various elements to be mastered in it. Ramalia; Nirmala, (2019) stated as a productive skill, writing is considered as a complex one, for it has several elements including, vocabulary, grammar, and paragraph organization. Besides, it also has the mechanics needed in order to produce a good writing, among other, punctuation, capitalization, spelling, unity, coherence, and organization. Those complexities become an obstacle for students to write. In accordance with Silva on Rinda, Novawan, \& Miqawati (2018) Besides, poor ability to transfer their ideas into words as they are incapable of selecting the appropriate words and the proper grammars is another difficulty that has to be handled carefully.

Using various kinds of method can be useful in writing class, so that students will experience a different impression in doing it. In accordance with technology, writing can be utilized with it. Richard on Le Van Canh (2015) stated that many new technological tools and online resources are available to support students' writing. Besides, it can increase their enthusiasm in writing. Social media is the example of technology that is suitable with the needs of students. As millennial generation, social media is very close with students' daily activity. Almost all of them have social media platform and use it in their daily life, whether just for having fun or looking for information. Lowedahl in Habibi et al. (2018) describes social media as web environments where content is aggregated, performed, and distributed. Social media can be utilized in teaching and learning activity by used it appropriately.

Instagram was the top five most popular social media platform in Indonesia. This survey was conducted in January 2020 by Hootsuite. It can be shown by the picture below.

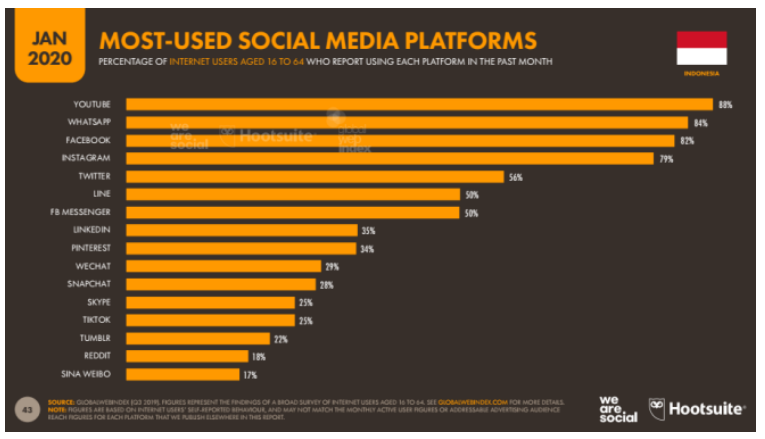

Figure1. Survey of most-used social media platforms in Indonesia by Hootsuite 
Tenia Ramalia ${ }^{1}$

J-SHMIC : Journal of English for Academic

Vol 8, No 2, August 2021

It can be seen that Instagram was in the $4^{\text {th }}$ most-used social media platform in Indonesia, after Youtube, Whatsapp and Facebook. Instagram is a social media platforms which let user share their photos, videos added with caption on it. It is enjoyable because we can get a lot of entertainments on it. We can see celebrity daily update right from their account, cooking recipes, funny videos, news and information, etc. According to Alhabash \& Ma (2017) Instagram is a mobile application that allows users to capture and share images and videos with followers. It has over 400 million active monthly users who shared over 40 billion pictures, with an average of 3.5 billion daily likes for $>80$ million photos shared daily. Instagram is a suitable platform used in writing class. It can be seen from the numbers of research conducted on this area of study. The participants in this study were students of $2^{\text {nd }}$ semester who learned some genre-based text, including the descriptive text. In this case, the researcher decided to use Instagram in teaching descriptive text because it is related to the feature of it where we can post pictures and add captions as the description of it. It is more fun and reliable because students can visualize what they write and write what they see from the picture. Thus, when using ICT especially social media, it is said to provide comfortable platform for the learners to be able to complete tasks given by the teacher and indirectly promotes autonomous learning environment (Al-Munawwarah in Shazali, Shamsudin, \& Yunus, 2019). Besides that, it is relatively practical to be administered and monitored every time and everywhere (Rinda et al., 2018). Thus, Instagram is appropriate to be used as a media in writing class related to its function and efficiency.

Many studies have proven the effectiveness of using Instagram in writing class. The study conducted by Shazali et al (2019) entitled Instagram: a Platform to improve students' writing ability, proved that using Instagram could help the students in developing their writing ability in terms of new vocabulary. Furthermore, it could boost their motivation too. It is also found that students gained better idea prior to writing task as their friend's post has been featured in the Instagram. Another study accomplished by Handayani (2016) entitled Instagram as a teaching tool? Really? said using Instagram allows students to generate ideas with contextually-relevant content and offers them a learning experience that they enjoy. In addition Gunantar \& Transinata (2019) in their paper Writing Caption on Instagram as Media for Student's Motivation and Writing Skill Improvement added another finding that by using photo-based media on Instagram, students could understand the material well. In addition, the use of direct examples of photos on Instagram in learning writing could help students to express their ideas broadly because the students could immediately see the photos displayed.

Based on the previous study above, it can be concluded that Instagram is effective in improving students' writing skill. Therefore, the researcher would like to do the research on in by finding out the students' perspective on using it. 


\section{METHOD}

This present study employed a case study research design to reveal the students' perspective of using Instagram for writing assignment. With respect to that, Baxter, Susan Jack, \& Jack (2008) supports that this qualitative case study is an approach to research that facilitates exploration of a phenomenon within its context using a variety of data sources.

The participants of this study consist of 61 students of $2^{\text {nd }}$ semester academic year 2019/2020 majoring in English Department at Universitas Islam Syekh-Yusuf Tangerang. The research is conducted during the course of Writing 2.

This study used open-ended questionnaire as the data collecting method. The items of questionnaire consist of seven statements which was inspired from Shazali, et al, (2019). Before distributing questionnaire to the participants, the writer did some steps of activity at class. Initially, the students did brainstorming after they were given some pictures of places on Instagram by the lecturer. It was conducted by showing the collection of pictures in Instagram through the projector. Students were also motivated to make a good caption to describe the picture of places displayed. After that, lecturer explained kind of genre text of it and its general structures. In the end of the meeting, students were asked to write a description of the favorite place they have ever visited added with the picture of it. They should post it on Instagram based on the due date given.

After checking the assignments, finally participants were given the questionnaire via Google form. There were seven premises to cover the purpose of the study. Participants were given two choices "agree" and "disagree" for questions. They are also given a blank space to write their reason of the answer. The question items are as follows:

1. I often use my Instagram account.

2. I usually write captions when posting pictures on Instagram.

3. Posting a writing assignment on Instagram can motivate me to write better.

4. Posting a writing assignment on Instagram help me to improve my writing skill.

5. Posting a writing assignment on Instagram is a fun activity.

6. Posting a writing assignment on Instagram is effective and efficient.

After collecting the data, the next step was data analysis. The data was using the Document analysis where the data is examined and interpreted in order to elicit meaning, gain understanding, and develop empirical knowledge (Corbin \& Strauss, 2008). The analytic procedure including finding, selecting, appraising (making sense of), and synthesizing data of the documents. Document analysis includes data excerpts, quotations, or entire passages that are organized into major themes, categories, and case examples specifically through content analysis (Labuschagne, 2003), then the researcher explained the excerpts of participants. 
Tenia Ramalia ${ }^{l}$

J-SHMIC : Journal of English for Academic

Vol 8, No 2, August 2021

\section{FINDING AND DISCUSSION}

\section{Finding}

The findings from the questionnaire indicated two major issues; the benefits and barriers of Instagram for writing assignment.

\section{I often use my Instagram account.}

As the writer has discussed before that features on Instagram make it becomes the most popular social media used, especially by teenager. eBizMBA (2016) found that Instagram is the eight most visited social media worldwide as well as Knight-McCord et al., (2016) stated that Instagram is the most used social media, followed by Snapchat and Facebook, so does the participants in this research. The researcher also got various responses from the participants responses on the questionnaire give. Most of the participants agreed with the premise. It means that most of them often use their Instagram account. They said that Instagram is fun. They can get information and entertainment through Instagram.

P3 On Instagram there are also many videos that contain education such as Islamic studies, information about seminars, etc.

P5 It gives me entertainment. On the other hand, I can also get information that becomes viral worldwide.

P40I can get various kinds of latest information.

While participants who disagreed with the statement said that it spent a lot of internet data plans.

P9 I'm not really interested on it.

P12 It spent a lot of internet data plans.

\section{I usually write captions when posting pictures on Instagram.}

Writing caption on the posted photograph is the basic feature of Instagram. As the technological changes, people nowadays tend to share their personal spaces on social media than on a personal diary. Akhiar, et al (2017) said that Instagram allows them to express thoughts and feelings through pictures and videos that is accompanied by texts. Similarly, the participants on this research mostly writing caption whenever they post a picture on Instagram.

P2 It is used to describe my feelings while I took a picture.

P8 The caption is important to describe more clearly about the photos we upload.

P10 It is as a description of the photos or videos that I uploaded.

While, some participants who disagreed have various reasons

P12 I'm not so good with words.

P49 Sometimes, I don't know what to write. 


\section{Posting a writing assignment on Instagram can motivate me to write better.}

Nearly all participants in this research agreed with the statement that Istagram can motivate them in writing. In line with this, Solomon (2013) argued that Instagram has gained a person's interest as well as confidence in expressing ideas virtually. It can be seen from their enthusiasm while doing the assignment of writing descriptive text because they can show their nice shot while writing the caption of it. In addition, Bell (2013) stated that Instagram has played a major role in enhancing the subjects learning, as shown in the statements below.

P1 Because by posting it on Instagram, it will be seen by many people, so that it can motivate me to write better.

P9 It is fun to collect assignments on social media.

P19 Since my writing can be seen by people, it encouraged me to make a good writing so that it can be useful for many people.

While the rest of participant stated disagree with the premise. The reasons are the same. They feel ashamed to post their assignment in public.

P43 I prefer to collect the assignment personally/privately; I feel ashamed to expose it to the public.

P45 Ifeel ashamed when I did mistake in writing.

\section{Posting a writing assignment on Instagram help me to improve my writing skill.}

Nearly all participant in this research agreed that Instagram can improve their writing skill. Purwandari (2017) found out that the photograph in instagram was effective to help them to improve their writing skill. Besides can motivate to study independently during the learning process. In the same year, a research from Muwafiqi (2017) argued that by using Instagram students will increase their writing skill because their picture can be seen by everyone. Thus, they will do their best in writing the caption of their photos or videos to showcase that they are good in writing. The following statements support the notion.

P16 I got to know the error of writing I made from the comments on Instagram.

P46 It is a teaching method that is in accordance with the time and it is so relate to the generation of the industrial revolution 4.0 era. I like it!

P52 It's easier to describe something on Instagram.

While others who disagree said that Instagram is not the only media for writing. P42I think improving writing ability not only from Instagram. 
Tenia Ramalia ${ }^{l}$

J-SHMIC : Journal of English for Academic

Vol 8, No 2, August 2021

\section{Posting a writing assignment on Instagram is a fun activity.}

Fun activity in learning is what is expected by every students and teachers in order to make learning circumstances more enjoyable and having a good outcome. Using Instagram as a media in writing is claimed to make the learning activity to be more fun. Gunantar, et al. (2019) mentioned that besides being fun, learning using Instagram could also trigger and encourage students' enthusiasm in learning writing. Almost all of the participants agreed with the notion. The following statements provide the evidence.

$P 2 \quad I t$ is fun because it's like we're telling stories virtually to people.

$P 27 \quad$ It can increase our creative ideas in writing.

P41 I can see my friends' writing so that I get new insight from the things they write.

However, there were 7 participants who disagreed that Instagram is fun for writing assignment. Here are the reasons:

P10 Personal assignment is private.

P47 I'd rather post it on Google Classroom.

\section{Posting a writing assignment on Instagram is effective and efficient.}

Most of the participants agreed that Instagram is effective and efficient to be used for writing media. Sari (2019) revealed that Instagram is an effective learning media to improve learners' writing skill, especially on the vocabulary range and grammatical accuracy. In addition, Mansor (2017) on his research related to Instagram for ESL classroom stated that Instagram was an efficient tool for students' interactions. Since Students can use it anytime and anywhere besides it is also paperless. The following statements clarify the notions.

P22 It can ease students and teachers/lecturers.

P25 We can reduce the waste from paper that is not used by submitting tasks online.

P26 Whenever I get many "like" from people, I become more enthusiastic in writing and developing my writing.

However, there were some participants who feel that Instagram is not effective for writing due to some reasons:

P12 Not everyone has Instagram account.

P45 I prefer to use Google Classroom for writing because I think Instagram is limited on space.

P47 I mind to open my private account setting.

\section{Discussion}

Regarding to the analysis and description above, it is found that most of participants are generally agreed posting writing assignment on Instagram is effective. This is in line with the research results conducted by Nurdiansyah, et. al (2020) Instagram can be used 
Tenia Ramalia ${ }^{l}$

J-SHMIC : Journal of English for Academic

Vol 8, No 2, August 2021

as an effective media in learning writing, for It can help the students to activate and boost their ability in writing. As the generation of digital, almost all of the participants

are familiar with many kinds of social media, including Instagram. They are also quite active in using it. Instagram gives them benefit whether as entertainment and information site.

Based on the students' perspective, Instagram is able to motivate them to write better and to improve their writing skill because they consider their writing can be read by others. Comments, feedback, and the 'like' buttons are also motivated them to improve their writing to be better. By looking directly at the photos, students can explore their ideas broadly in writing. They also find out that this method is fun because they try to get creative ideas to write. Besides they also got a new insight from their friends' writing. Thus, at this point they can learn autonomously. As Preece, J and Shneiderman (2009) revealed that students would be more active in producing their knowledge through the use of social technologies because they had a space to expose and explore themselves to publish their work online.

According to the survey conducted, it also revealed that Instagram is effective and efficient to submit writing assignment. They find it easy and simple to do the task. Gunantar \& Transinata (2019) mention that photos in Instagram can ease students to understand the material. They can review their work repeatedly and edit it whenever they find error. A student even considered that this method can reduce the paper waste from doing a conventional writing by pen and paper.

The last one, on the barriers of using Instagram for writing assignment is some students find its difficulty in the signal and data plans. Considering that Indonesia consist of mountains and low areas that causing the signal unstable. Besides, the limited internet access of some students also could be the barrier in using internet for learning activity. This is in line with a research conducted by Renaldi (2017) stated that the barrier that often appear in using Instagram as a media for teaching is in term of time, capability and cost. Hence, the providers are expected to increase their quality in signal services and lower prices to facilitate students' needs in learning (Hidayati, et al, 2021). This statement is support by Rooksby, Weckert and Lucas's (2002) that mentioned access, ability, and affordability are the important components to technology readiness. Besides, there is also another issue that they revealed, like privacy. Some of them felt that it is a personal assignment and it does not need to be published in public because they feel unconfident of their writings. However, it is related to the term and condition of the platform that should be concerned by the user. Gelatt (1995) stated that we must be ready for changes since the changes are so rapid, turbulent, and unpredictable. Thus, the students must be provided with digital literacy to ease them adapt to the development of technology.

\section{CONCLUSION AND SUGGESTION}

The findings of this study showed that Instagram is effective for writing assignment. They feel that writing their ideas on Instagram was such a fun activity. They can 
Tenia Ramalia ${ }^{1}$

J-SHMIC : Journal of English for Academic

Vol 8, No 2, August 2021

generate ideas easily because they have a straight visualization on the photo they write. Instagram also can boost the students' motivation in writing. They are motivated by their friends' post so they are inspired to do better. Besides, people's attention through 'like' button and comments also boost their motivation to write better. However, teachers' role is also important to help students in using the platform effectively. In short, Instagram can be one of useful teaching media, especially for writing as long as it is used and supervised appropriately.

The researcher hopes that this study can give another insight about using technology and social media namely Instagram as a platform for writing assignment. Furthermore, the researcher thought that gender differences in utilizing technology, especially in using Instagram for learning English might also be an exciting area to be discussed.

\section{REFERENCES}

Akhiat, Ayuni; Mydin, Al- Amin; Adi Kasuma, Shaidatul Akma. Students' Perceptions And Attitudes Towards The Use Of Instagram In English Language Writing. Malaysian Journal of Learning and Instruction, [S.1.], p. 47-72, dec. 2017. ISSN 2180-2483. Available at: <http://ejournal.uum.edu.my/index.php/mjli/article/view/mjli.2017.7796>. Date accessed: 28 aug. 2021. doi: https://doi.org/10.32890/mjli.2017.7796.

Alhabash, S., \& Ma, M. (2017). A Tale of Four Platforms: Motivations and Uses of Facebook, Twitter, Instagram, and Snapchat Among College Students? Social Media and Society, 3(1). https://doi.org/10.1177/2056305117691544

Baxter, P., Susan Jack, \& Jack, S. (2008). Qualitative Case Study Methodology: Study Design and Implementation for Novice Researchers. The Qualitative Report Volume, 13(4), 544-559. https://doi.org/10.2174/1874434600802010058

Bell, M. A. (2013). Picture this! Using Instagram with students. Internet@Schools, 20(4), pp. 23-25

Corbin, J., \& Strauss, A. (2008). Basics of Qualitative Research: Techniques and Procedures for Developing Grounded Theory (3rd ed.).

Gelatt, H. B. (1995). Future sense: Creating the future. The Futurist, 3 (2), 35-43.

Gunantar, D. A., \& Transinata, T. (2019). Writing Caption on Instagram as Media for Student's Motivation and Writing Skill Improvement. ETERNAL (English Teaching Journal), 10(1). https://doi.org/10.26877/eternal.v10i1.3905

Habibi, A., Mukminin, A., Riyanto, Y., Prasojo, L. D., Sulistiyo, U., Sofwan, M., \& Saudagar, F. (2018). Building an online community: Student teachers' perceptions on the advantages of using social networking services in a teacher education program. Turkish Online Journal of Distance Education, 19(1), 46-61. https://doi.org/10.17718/tojde.382663

Handayani, F. (2016). Instagram as a Teaching Tool? Really? Proceedings of the Fourth International Seminar on English Language and Teaching (ISELT-4), 320-327. 
Tenia Ramalia ${ }^{l}$

J-SHMIC : Journal of English for Academic

Vol 8, No 2, August 2021

Hidayati, AN., et al (2021). Leveraging Skype-Based Webinars as An English Language Learning Platform. Al- Ishlah: Jurnal Pendidikan, June 2021, 13 (1), Pages 10 - 20. DOI: 10.35445/alishlah.v13i1.420

Knight-McCord, J., Cleary, D., Grant, N., Herron, A., Lacey, T., Livingston, T., \& Emanuel, R. (2016). What social media sites do college students use most. Journal of Undergraduate Ethnic Minority Psychology, 2(21), 21-26

Labuschagne (2003). Qualitative Report 8(1):100-103. DOI:10.46743/2160$3715 / 2003.1901$

Le Van Canh. (2015). Key issues in language teaching [Book Review]. English Australia Journal, 32(1), 113-116.

Mansor, N., \& Rahim, N. (2017). Instagram in ESL Classroom. Man in India, 97, 107114.

Muwafiqi, M. A. (2017). The use of Instagram to increase students' writing skill. Proceedings of The Fifth Undergraduate Conference on ELT, Linguistics, and Literature 2017 (pp. 213-219). Yogyakarta: Sanata Dharma University Press

Nurdiansyah,A. and Abdulrahman, TR. (2020). The Use Of Instagram To Develop Students'writing Ability. Akademika: Jurnal Teknologi Pendidikan 9 (01), 97-107

Preece, J and Shneiderman, B. (2009). T ransactions on H uman - C omputer I nteraction THCI AIS Transactions on Human-Computer Interaction. AIS Transactions on Human-Computer Interaction, 3(1), 1-25. https://doi.org/10.5121/ijfcst.2014.4403 Purwandari, M. (2017). The Use of Photographs on Instagram in Teaching Descriptive Text To Improve Students' Writing Skill. ELT Forum: Journal of English Language Teaching, 6(2), 133-141. https://doi.org/10.15294/elt.v6i2.20694

Ramalia, Tenia; Nirmala, N. (2019). Jurnal Ilmu Pendidikan dan Ilmu Sosial Using Clustering Technique in Teaching Writing. Jurnal Ilmu Pengetahuan Dan Ilmu Sosial, 28(1), 19-23.

Rinda, R. K., Novawan, A., \& Miqawati, A. H. (2018). Students 'perspectives on social media-based learning of writing through Instagram. 5(1), 23-33.

Rooksby, E., Weckert, J., \& Lucas, R. (2002). The rural digital divide: the ruralsociety. Rural Society, 12(3), 197-210. DOI: 10.5172/rsj.12.3.197

Sari, FM. and Wahyudin, AY (2019). Undergraduate Students' Perceptions Toward Blended Learning Through Instagram In English For Business Class. International Journal of Language Education 3(1):64-73. DOI:10.26858/ijole.v1i1.7064

Shazali, S. S., Shamsudin, Z. H., \& Yunus, M. M. (2019). Instagram: A Platform to Develop Student's Writing Ability. International Journal of Academic Research in Business and Social Sciences, 9(1), 88-98. https://doi.org/10.6007/ijarbss/v9i1 $1 / 5365$

Salomon, D. (2013). Moving on from Facebook Using Instagram to connect with undergraduates and engage in teaching and learning. College \& Research Libraries News, 74(8), pp. 408-412. 
Tenia Ramalia ${ }^{1}$

J-SHMIC : Journal of English for Academic

Vol 8, No 2, August 2021 